\title{
IMPACTO DEL PAGO POR SERVICIOS AMBIENTALES HIDROLÓGICOS EN LOS BOSQUES DE TRES EJIDOS DE TEXCOCO, MÉXICO
}

\section{IMPACT OF PAYMENT FOR HYDROLOGICAL ENVIRONMENTAL SERVICES IN FORESTS FROM THREE EJIDOS IN TEXCOCO, MÉXICO}

\author{
Mónica Ruiz-Jiménez, Esteban Valtierra-Pacheco* \\ Campus Montecillo, Colegio de Postgraduados. Km.36.5 Carretera México-Texcoco. \\ Montecillo, Texcoco, Estado de México. 56230. (evaltier@colpos.mx)
}

\begin{abstract}
RESUMEN
El objetivo del estudio es analizar la situación de los predios forestales ejidales después de haber participado en el Programa de Servicios Ambientales Hidrológicos (PSAH) de la Comisión Nacional Forestal (CONAFOR) de 2005 a 2010. $\mathrm{Al}$ inicio los tres predios forestales estaban clasificados como “En reposo"; esto es, que no se les hacía aprovechamiento de la madera. Durante este período, la condición del bosque de los tres predios participantes en el PSAH mejoraron por las obras de conservación de suelos y reforestación, y porque durante los cinco ańos no se hicieron aprovechamientos maderables. En 2011, los ejidos decidieron reiniciar el aprovechamiento maderable en dos de los predios beneficiados cuando finalizó el pago por servicios ambientales. Sin embargo, el tercer predio fue preservado como área de conservación. Esto significa que el pago hecho por la CONAFOR a través del PSAH no garantiza la conservación de los bosques ni la provisión de servicios ambientales en el largo plazo.
\end{abstract}

Palabras clave: conservación de bosques, predios forestales, aprovechamientos maderables, reforestación, obras de conservación.

\section{INTRODUCCIÓN}

L as aguas dulces del mundo constituyen un recurso cada vez más escaso, amenazado y en riesgo de ser contaminado. El agua subterránea es una fuente de agua dulce de alta calidad y representa a un tercio de todos los depósitos de agua dulce en el mundo. Más de $40 \%$ de esta agua es utilizada para cuestiones agrícolas, seguida del uso doméstico (más de $30 \%$ ) y el uso en la industria (más de $20 \%$ ) (Taylor et al., 2013).

* Autor responsable * Author for correspondence.

Recibido: noviembre, 2013. Aprobado: noviembre, 2016.

Publicado como ARTÍCULO en ASyD 14: 511-531. 2017.

\section{Abstract}

The objective of this study is to analyze the situation of ejido forest properties after having participated in the Program for Hydrological Environmental Services (PSAH) of the National Forest Commission (CONAFOR) from 2005 to 2010. At the beginning the three forest properties were classified as "Resting"; that is, that they were not used for timber extraction. During this period, the condition of the forest in the three properties participating in the PSAH improved, due to the soil conservation and reforestation works, and because during the five years there was no timber extraction. In 2011, the ejidos decided to restart timber exploitation in two of the properties benefitted when the payment for environmental services ended. However, the third property was preserved as a conservation area. This means that the payment made by the CONAFOR through the PSAH does not guarantee the conservation of forests or the provision of environmental services in the long term.

Key words: forest conservation, forest properties, timber extraction, reforestation, conservation works.

\section{INTRODUCTION}

$\mathrm{F}$ resh water in the world constitutes an increasingly scarce resource, threatened and at risk of being contaminated. Underground water is a source of fresh water of high quality and represents a third of all the fresh water deposits in the world. More than $40 \%$ of this water is used for agriculture, followed by domestic use (more than $30 \%$ ), and industry use (more than $20 \%$ ) (Taylor et al., 2013).

Underground water performs a fundamental role in the maintenance of ecosystems. Water is intercepted by forest vegetation, the quality and 
El agua subterránea desempeña un papel fundamental en el mantenimiento de los ecosistemas. El agua es interceptada por la vegetación forestal, la calidad y la cantidad de agua depende de diferentes factores, tales como edad de la vegetación, especie, estado fitosanitario del bosque y las actividades silvícolas que se realicen con la vegetación; por consiguiente, la pérdida de superficie forestal afecta la cantidad y calidad de agua (González-Guillén et al., 2006).

El aumento poblacional, la fuerte competencia por espacios para la agricultura y la demanda creciente de madera han desencadenado un vertiginoso proceso de deforestación que sigue afectando a unos 13 millones de hectáreas al año (Montes y Sala, 2007). De 1990 a 2000 se deforestaron en México un promedio de 354 mil hectáreas anuales, y de 2005 a 2010 la tasa de deforestación se redujo a $155 \mathrm{mil}$ hectáreas anuales (CONAFOR, 2011).

La deforestación es uno de los principales factores que acentúan el llamado cambio climático, el cual puede repercutir gravemente en la recarga del agua dulce en el subsuelo. Algunos estudios (Allan y Soden, 2008; Bates et al., 2008) señalan que los efectos futuros del cambio climático en la recarga de agua dulce pueden ser muy graves debido a que los períodos de sequía pueden ser más prolongados, mientras que las precipitaciones serán menos frecuentes, pero en mayor intensidad (provocando inundaciones y menor agua infiltrada al subsuelo).

Una de las medidas implementadas a partir de los años noventa para la conservación de los bosques y mantener la provisión de agua destinada al consumo humano y a las actividades productivas fue el pago de servicios ambientales hidrológicos a los dueños de los bosques y selvas. Porras et al. (2008) realizaron un estudio que comprendió 287 casos de esquemas de pago por servicios ambientales hidrológicos en países en desarrollo.

Los programas de pago por servicios ambientales promovidos por los gobiernos nacionales o locales buscan ser mecanismos temporales de pago que hace el Estado a los dueños de los bosques y selvas en tanto se forma un mercado por servicios ambientales en donde los consumidores de agua paguen alguna cantidad de dinero a los dueños de los bosques para su conservación, que permita mantener la infiltración de agua subterránea y los escurrimientos hasta los cauces superficiales.

López-Morales (2012) señala que, de acuerdo con estadísticas oficiales de la Comisión Nacional del quantity of water depends on different factors, such as age of the vegetation, species, phytosanitary state of the forest, and forestry activities carried out with the vegetation; therefore, the loss of forest surface affects the quantity and quality of water (GonzálezGuillén et al., 2006).

The population increase, the strong competition over spaces for agriculture and the growing demand for timber have unchained a vertiginous process of deforestation that continues to affect about 13 million hectares per year (Montes and Sala, 2007). From 1990 to 2000 an average of 354 thousand hectares was deforested annually, and from 2005 to 2010 the deforestation rate was reduced to 155 thousand hectares annually (CONAFOR, 2011).

Deforestation is one of the main factors that accentuate climate change, which can gravely impact the fresh water reload in the subsoil. Some studies (Allan and Soden, 2008; Bates et al., 2008) point out that the future effects of climate change on the fresh water reload can be quite serious because the drought periods may be longer, while the rainfall less frequent, but of higher intensity (causing flooding and less water infiltration to the subsoil).

One of the measures implemented since the 1990s for the conservation of forests and to maintain the water supply destined to human consumption and to productive activities was payment for hydrological environmental services to the owners of the forests and rainforests. Porras et al. (2008) performed a study that included 287 cases of payment plans for hydrological environmental services in developing countries.

Programs of payment for environmental services promoted by national or local governments seek to be temporary payment mechanisms that the State makes to owners of the forests and rainforests while a market for environmental services is formed where water consumers pay some amount of money to the forest owners for their conservation, allowing to maintain underground water infiltration and runoffs toward superficial channels.

López-Morales (2012) points out that, according to official statistics from the National Water Commission (Comisión Nacional del Agua) in 2011, up to 2.3 times the volume of renewable flow (superficial and underground) is used in the central zone of the country, which generates the highest regional water stress indicators in the country. In 
Agua en 2011, en la zona centro del país se utiliza anualmente hasta 2.3 veces el volumen del flujo renovable (superficial y subterráneo), lo que genera los indicadores de estrés hídrico regional más elevados del país. En particular, la extracción anual de agua subterránea, que provee alrededor de $70 \%$ del agua utilizada en la región, equivale a alrededor de dos veces el volumen de recarga del sistema de acuíferos, lo que genera un conjunto de problemas que incluye hundimientos, disminuciones del nivel freático, pérdida de calidad o incrementos en el costo de extracción.

Por tal razón, y con el objetivo de proteger la capacidad de provisión de los servicios ambientales hidrológicos, en 2003 el Gobierno Mexicano implementó el Programa de Servicios Ambientales Hidrológicos (PSAH) (SEMARNAT, 2003). Algunos de estos servicios ambientales son: mantenimiento de la capacidad de recarga de los mantos acuíferos y mantenimiento de la calidad de agua, conservación de manantiales, entre otros (Ruiz-Pérez et al., 2007).

El principal objetivo del PSAH es asegurar la permanencia y conservación de los ecosistemas forestales, a través de una compensación económica que la CONAFOR otorga a los dueños y poseedores de los bosques y selvas que deciden conservar sus áreas forestales arboladas para proveer servicios hidrológicos a la sociedad (SEMARNAT, 2003).

El supuesto del que parte la CONAFOR es que la cobertura vegetal de México no solo puede conservarse, sino que puede incrementarse pagándole a los propietarios de la tierra por los servicios ambientales (externalidad positiva) que proveen, ya sea utilizando sistemas sostenibles de producción, reforestando y/o conservando los bosques.

Basado en las Cartas de Uso del Suelo y Vegetación elaborados por INEGI, el análisis de CONAFOR muestra que la tasa de pérdida neta de bosques ha disminuido a la mitad entre 2005 y 2010 en México (CONAFOR, 2011).

Sin embargo, uno de los principales problemas que enfrenta el PSAH es la falta de alternativas para los dueños del bosque, una vez que el programa ha llegado a su fin. Son muy pocos los casos donde se han generado esquemas locales de pago por servicios ambientales o se ha facilitado el acceso a esquemas voluntarios de pago por servicios ambientales. Esto indica que, después de los cinco años de apoyo del programa, no existe una garantía de que los productores continúen conservando particular, the annual extraction of underground water, which provides around $70 \%$ of the water used in the region, is equivalent to about two times the reload volume of the aquifer system, generating a group of problems that includes sinking, decrease of water table levels, loss of quality, or increases in the cost of extraction.

Therefore, and with the objective of protecting the supply capacity of hydrological environmental services, in 2003 the Mexican Government implemented the Program for Hydrological Environmental Services (Programa de Servicios Ambientales Hidrológicos, PSAH) (SEMARNAT, 2003). Some of these environmental services are: maintenance of the reload capacity of aquifer tables and maintenance of the quality of water, conservation of water sources, among others (RuizPérez et al., 2007).

The main objective of the PSAH is to guarantee the permanence and conservation of forest ecosystems, through economic compensation that CONAFOR grants the owners and holders of forests and rainforests who decide to conserve their treecovered forest areas to provide hydrological services to society (SEMARNAT, 2003).

The assumption that CONAFOR starts from is that the vegetation coverage in México cannot only be conserved, but rather it can be increased by paying the land owners for the environmental services (positive externality) they provide, whether by using sustainable production systems, reforesting and/or conserving forests.

Based on the Soil and Vegetation Use Charts elaborated by INEGI, the analysis by CONAFOR shows that the rate of net forest loss has decreased in half between 2005 and 2010 in México (CONAFOR, 2011).

However, one of the main problems that the PSAH faces is the lack of alternatives for the forest owners, once the program has reached its end. There are very few cases where local schemes for payment of environmental services have been generated or where access to voluntary payment plans for environmental services has been facilitated. This indicates that, after the five years of backing from the program, there is no guarantee that producers will continue to conserve the properties supported, and that the conditions present before participating in the program will not return, or else, that they will begin performing timber extraction. 
los predios apoyados y no regresen a las condiciones que tenían antes de participar en el programa, o bien, que inicien su aprovechamiento maderable.

El PSAH debe marcar la diferencia en la conservación de los predios beneficiados y en la provisión de servicios ambientales hidrológicos; de lo contrario, este programa estaría fungiendo solo como un programa más de subsidio temporal y no garantiza la conservación del bosque una vez que el productor ya no reciba el apoyo económico.

El principal objetivo de esta investigación es conocer qué sucedió con los predios forestales ejidales después de haber participado en el Programa de Servicios Ambientales Hidrológicos (PSAH) de la Comisión Nacional Forestal (CONAFOR) de 2005 a 2010. La hipótesis del presente estudio es que los apoyos del PSAH mejoran las condiciones de los bosques, pero no garantizan que los bosques beneficiados con los subsidios mantengan la provisión de servicios ambientales en el mediano o largo plazo, una vez concluido el flujo de subsidios.

\section{Metodología}

\section{Área de estudio}

La investigación se realizó en tres ejidos del municipio de Texcoco, Estado de México: Ejido San Miguel Tlaixpan, Ejido San Pablo Ixayoc y Ejido Tequexquinahuac. Los tres ejidos se localizan en el área forestal conocida como "zona de montaña", que es la parte más alta del municipio y donde se ubican la mayoría de los ejidos y comunidades forestales.

Este municipio se localiza en las estribaciones orientales de la cuenca endorreica denominada "Valle de México", a una distancia de $25 \mathrm{~km}$ de la Ciudad de México, entre las coordenadas geográficas: Longitud 98 39' $28^{\prime}$ "W y 9901' 45” W; Latitud Mínima: $19^{\circ} 23^{\prime} 40^{\prime \prime} \mathrm{N}$ y $19^{\circ} 33^{\prime} 41^{\prime \prime}$. La extensión territorial es de 418.69 kilómetros cuadrados y se localiza en el oriente del Estado de México, a una distancia aproximada de veinticinco kilómetros de la Ciudad de México ${ }^{1}$.

El presente estudio se realizó en el municipio de Texcoco que cuenta, de acuerdo con el censo del INEGI (2010), con una población de 235151 personas; sin embargo, comparte el acuífero con Chicoloapan, Chimalhuacan y Nezahualcoyotl, que son de los municipios con mayor cantidad y densidad de
The PSAH must mark the difference in the conservation of the properties benefitted and in the provision of hydrological environmental services; on the contrary, this program will be functioning only as another program for temporary subsidy and will not guarantee forest conservation once the producer ceases to receive the financial support.

The main objective of this study is to understand what happened to ejido forest properties after having participated in the Program for Hydrological Environmental Services (PSAH) of the National Forest Commission (Comisión Nacional Forestal, CONAFOR) from 2005 to 2010. This study's hypothesis is that backing from the PSAH improves the conditions of forests, but does not guarantee that the forests benefitted with the subsidies will maintain the provision of environmental services in the medium and long term, once the flow of subsidies ends.

\section{Methodology}

\section{Study area}

The research was carried out in three ejidos of the municipality of Texcoco, Estado de México: Ejido San Miguel Tlaixpan, Ejido San Pablo Ixayoc and Ejido Tequexquinahuac. The three ejidos are located in the forest area known as "mountainous zone", which is the highest part of the municipality and where most of the forest ejidos and communities are located.

This municipality is located in the eastern foothills of the endorheic basin called "Valle de México", at a distance of $25 \mathrm{~km}$ from Mexico City, between geographic coordinates: Longitude $98^{\circ} 39^{\prime} 28^{\prime \prime} \mathrm{W}$ and $99^{\circ} 01^{\prime} 45^{\prime \prime} \mathrm{W}$; Minimum Latitude: $19^{\circ} 23^{\prime} 40$ " $\mathrm{N}$ and $19^{\circ} 33^{\prime} 41^{\prime \prime}$. The territorial extension is 418.69 square kilometers and located in eastern Estado de México, at an approximate distance of 25 kilometers from Mexico City ${ }^{1}$.

This study was performed in the municipality of Texcoco which has, according to the INEGI (2010) census, a population of 235151 people; however, it shares the aquifer with Chicoloapan, Chimalhuacan and Nezahualcoyotl, which are among the municipalities with highest population number and density in the country. This situation makes the aquifer on which Texcoco is settled one of the 
población del país. Esta situación hace que el acuífero sobre el que se asienta Texcoco sea uno de los más sobreexplotados de todo el país. De acuerdo con la Comisión Nacional del Agua (CONAGUA), Texcoco se localiza en la Zona de Extracción de Agua 9-01 Valle de México, cuya condición hidrológica es de sobreexplotación extrema, por lo que ha sido declarada como zona de veda para la apertura de nuevos pozos. Escobar y Palacios (2012) calcularon la tasa de sobreexplotación del acuífero en $-67.61 \mathrm{hm}^{3}$ año ${ }^{-1}$, que se traduce en un abatimiento del manto freático promedio anual de 1.20 metros en el periodo 1969 2009.

Por tal motivo, este acuífero fue seleccionado por la CONAFOR y PROBOSQUE como zona para apoyar acciones de recarga de acuíferos a través de servicios ambientales.

\section{Método de estudio de caso}

La investigación se realizó en 2012, con base en el método de estudio de caso. Este tiene un carácter cualitativo y descriptivo, principalmente, aun cuando se recopila información tanto cualitativa (entrevistas estructuradas flexibles, observación y otras) como cuantitativa (archivos, mediciones en campo, y otras). Los resultados de este método no pueden inferirse hacia una población mayor, pero permite un examen y escrutinio a profundidad de la recopilación de una gran cantidad de datos detallados, permitiendo una imagen completa de un fenómeno social (Salkind, 1999).

Rodríguez (1996) menciona que un estudio de casos múltiples presenta evidencias más convincentes y, por tanto, el estudio es más robusto; por ello, se seleccionaron tres casos.

\section{Muestreo}

La selección de los tres ejidos se hizo con base en tres características comunes: 1) se ubican en la misma zona forestal del municipio de Texcoco; 2) fueron beneficiarios del Programa Federal de Pago por Servicios Ambientales Hidrológicos durante el período 2005-2010; y 3) ya concluyeron los cinco años de apoyo de dicho programa.

Se realizó un muestreo dirigido no probabilístico porque los beneficiarios del PSAH son los ejidos y no los ejidatarios individuales, por lo cual la mayor most overexploited in the whole county. According to the National Water Commission (CONAGUA), Texcoco is located in the Water Extraction Zone 9-01 Valle de México, whose hydrological condition is of extreme overexploitation, which is why it has been declared as a closed zone for the opening of new wells. Escobar and Palacios (2012) calculated the rate of aquifer overexploitation in $-67.61 \mathrm{hm}^{3}$ year $^{-1}$, which translates into an average annual reduction of the water table of 1.20 meters during the period 1969-2009.

For this reason, this aquifer was selected by CONAFOR and PROBOSQUE as a zone to support actions for the recharge of aquifers through environmental services.

\section{Case study method}

The study was performed in 2012, based on the case study method. This has a qualitative and descriptive character, primarily, even when both qualitative (flexible structured interviews, observation and others) and quantitative (archives, field measurements, and others) information is gathered. The results from this method cannot be inferred for a larger population, but they allow an examination and in-depth scrutiny from the gathering of a large amount of detailed data, allowing a complete image of a social phenomenon (Salkind, 1999).

Rodríguez (1996) mentions that a study of multiple cases presents more convincing evidences and, therefore, the study is more robust; because of this, three cases were selected.

\section{Sampling}

The selection of the three ejidos was made based on three common characteristics: 1) they are located in the same forest zone of the municipality of Texcoco; 2) they were benefitted by the Federal Program for Hydrological Environmental Services during the 2005-2010 period; and 3) the five years of backing from this program had already concluded.

Non-probabilistic directed sampling was carried out because the PSAH beneficiaries are the ejidos and not the individual ejidatarios, which is why most of them did not understand the process of negotiating the backing and many didn't even receive payments for their workdays because they did not work in the tasks 
parte de ellos no conocían el proceso de gestión de los apoyos y muchos ni siquiera recibieron pagos por sus jornales porque no trabajaron en las obras realizadas en los predios beneficiados. Por tal motivo, la mayor parte de la información provino de informantes clave que fungían como representantes ejidales en la gestión de los apoyos del PSAH y fueron quienes organizaron los trabajos de conservación en los predios beneficiados por el programa.

Se tomó una muestra de cuota de cinco ejidatarios por ejido (15 en total) que hubieran participado en la construcción de obras y labores de conservación de los predios beneficiados. A los ejidatarios solo se les realizaron algunas preguntas para corroborar aspectos que conocían como, por ejemplo, la rendición de cuentas de los recursos del PSAH, o bien, sobre información que les atañía, como el pago de jornales que recibieron por su trabajo en las obras de conservación. Por ello, esta muestra de ejidatarios no puede considerarse representativa y solo tenía la función de detectar incongruencias, imprecisiones o explicaciones dadas por el informante clave. Al final no se encontraron discrepancias significativas entre los dirigentes y los ejidatarios.

Por último, se hizo una entrevista con el Prestador de Servicios Técnicos Forestales (PSTF) de cada ejido. Se diseñó un cuestionario con un enfoque mucho más técnico, pero también repitiendo algunos puntos para verificar la información obtenida con los informantes clave y los ejidatarios escogidos al azar.

\section{Instrumentos de investigación}

Entrevistas estructuradas: Se diseñaron tres cuestionarios que sirvieron para recopilar información a través de entrevistas directas con los actores sociales: informantes clave, ejidatarios y personal asesor técnico.

Recorridos de campo: Se realizaron recorridos de campo en los tres ejidos, visitando los predios forestales que participaron en el programa de PSAH con la finalidad de conocer las diferentes prácticas y obras de conservación que se hicieron al bosque durante el período de apoyo, así como conocer el estado actual de los mismos una vez concluido el apoyo de dicho programa. En los tres casos se designó una comisión integrada por dos o más personas de cada ejido que conocieran perfectamente el lugar y que hubieran estado involucrados plenamente en las actividades del PSAH. carried out on the properties benefitted. Therefore, the greatest part of the information came from key informants who functioned as ejido representatives in the management of PSAH supports and were the ones who organized the conservation works in the properties benefitted by the program.

A quota sample was taken of five ejidatarios per ejido (15 in total) who had participated in the construction of conservation works and tasks in the properties benefitted. The ejidatarios were asked only a few questions to corroborate aspects that they knew about, such as, for example, accountability of the PSAH resources, or else, about information that would interest them, such as payment of workdays that they received for their work in the conservation tasks. Therefore, this sample of ejidatarios cannot be considered representative and only had the function of detecting inconsistencies, imprecisions, or explanations given by the key informant. In the end, no significant discrepancies were found between the leaders and the ejidatarios.

Lastly, an interview was performed with the Forest Technical Services Provider (Prestador de Servicios Técnicos Forestales, PSTF) from each ejido. A questionnaire was designed with a much more technical approach, but also repeating some points to verify the information obtained with the key informants and ejidatarios chosen randomly.

\section{Research instruments}

Structured interviews: Three questionnaires were designed that served to gather information through direct interviews with the social actors: key informants, ejidatarios and technical advisory staff.

Field visits: Field visits were carried out in the three ejidos, visiting the forest properties that participated in the PSAH program with the aim of understanding the different conservation practices and tasks that were performed in the forest during the period of backing, as well as understanding their current state once the support from the program ended. In the three cases a commission was designated, integrated by two or more people from each ejido who knew the place perfectly well and who had been fully involved in the PSAH activities.

Participant observation: It is a research and learning method through which the researcher is exposed and becomes involved in the day-to-day life 
Observación participante: Es un método de investigación y de aprendizaje a través de del cual el investigador se expone e involucra en el día a día o las actividades de rutina de los participantes (Kawulich, 2005). La información se obtuvo en varias visitas a los ejidos donde se observaron las actividades de los ejidatarios, realizando actividades relacionadas con el bosque.

\section{Resultados}

\section{Condición de los predios beneficiados, antes de participar en el programa PSAH}

La especie forestal predominante en los tres ejidos fue el Abies religiosa (oyamel), ocupando más de $60 \%$ de la superficie total de cada uno de los predios. Lo anterior se debió a las características altitudinales de dichos predios (arriba de los $2500 \mathrm{~m}$ ). La segunda especie predominante fue el pino (Pinus hartwegii, Pinus pseudostrobus, Pinus montezumae (ocote) y en menor porcentaje el encino (Quercus spp.).

$\mathrm{Al}$ iniciar su participación en el programa, los tres predios estaban contemplados dentro del programa de manejo forestal de cada ejido, solo que en estatus de "recuperación o reposo". Esto significa que durante los cinco años de apoyo no podían ser aprovechados para permitir que el arbolado forestal se fortaleciera. En 2005 los predios de los ejidos de Tequexquinahuac y San Pablo Ixayoc estaban en espera de ser aprovechados y en el caso del ejido de San Miguel Tlaixpan el predio acababa de ser aprovechado.

De acuerdo con la información obtenida, una de las principales razones para participar en el PSAH no fue solo para seguir cuidando y conservando el bosque, sino porque el predio participante estaba en ese momento en descanso.

En los tres casos la superficie apoyada fue de 200 hectáreas ubicadas en un solo predio o polígono. Esta coincidencia se debe a que en 2005 el área en recuperación o reposo no debía exceder de 200 hectáreas por beneficiario. Por lo tanto, cada ejido no podía aspirar a participar con una superficie mayor.

En los tres casos los predios participantes no eran las áreas con mayor riesgo de deforestación ni eran áreas abandonadas, sino que estaban incluidos dentro del Programa de Manejo Forestal del Ejido. Incluso en el ejido de San Miguel Tlaixpan el predio participante era la zona mejor conservada del bosque. or routine activities of the participants (Kawulich, 2005). The information was obtained during several visits to the ejidos where activities of the ejidatarios were observed, performing activities related to the forest.

\section{Results}

\section{Condition of the properties benefitted, before participating in the PSAH program}

The predominant forest species in the three ejidos was Abies religiosa (sacred fir), occupying more than $60 \%$ of the total surface of each one of the properties. This was due to the altitudinal characteristics of these properties (above 2500 masl). The second predominant species was pine (Pinus hartwegii, Pinus pseudostrobus, Pinus montezumae (ocote) and in a lower percentage, oak (Quercus spp.).

At the beginning of their participation in the program, the three properties were contemplated within the forest management program of each ejido, except under status of "in recovery or rest". This means that during the five years of backing they could not be exploited to allow the forest tree cover to become stronger. In 2005 the properties in the ejidos of Tequexquinahuac and San Pablo Ixayoc were waiting to be exploited, and in the case of the ejido of San Miguel Tlaixpan the property had just been exploited.

According to the information obtained, one of the main reasons to participate in the PSAH was not only to continue caring for and conserving the forest, but also because the participating property was resting at that moment.

In the three cases the surface backed was 200 hectares located in a single property or polygon. This coincidence is because in 2005 the area in recovery or rest did not have to exceed 200 hectares per beneficiary. Therefore, each ejido could not aspire to participate with a larger surface.

In the three cases the participating properties were not the areas with highest risk of deforestation, nor were they abandoned areas, but rather they were included within the ejido's Forest Management Program. Even in the ejido of San Miguel Tlaixpan, the participating property was the best conserved zone of the forest. 


\section{Pagos por servicios ambientales hidrológicos}

El mecanismo de apoyo principal del PSAH hacia los ejidos fue la transferencia de recursos económicos a cambio de dos condiciones principales: 1) no realizar aprovechamientos maderables en los predios beneficiados; y 2) realizar obras y labores de conservación para mejorar las condiciones ecológicas de los predios para mantener las cubierta vegetal.

En 2005, el PSAH pagó una cuota de $\$ 300.00$ $\mathrm{ha}^{-1}$, lo que significó una cantidad de $\$ 60000.00$ anuales por las 200 ha de cada predio beneficiado. El dinero debería ser destinado al pago de jornales, servicios y materiales necesarios para la realización de obras y actividades de conservación. Al preguntarle a los ejidatarios en que fueron invertidos los recursos, el ejido de Tequexquinahuac y el de San Pablo Ixayoc señalaron que fueron destinados enteramente a las acciones de conservación del bosque y en el ejido de San Miguel Tlaixpan se destinó $60 \%$ a acciones de conservación y $40 \%$ a construir el salón ejidal.

Ninguno de los ejidos destinó dinero para repartir a los ejidatarios, por lo cual la única forma de beneficio económico fue el pago por jornales para realizar las obras de conservación. En las entrevistas los informantes clave y los ejidatarios coincidieron en que la cuota pagada por el PSAH es demasiado baja y que ni siquiera cubre los costos de darle un buen mantenimiento al bosque. La mayoría coincidió que la cuota debería ser de al menos $\$ 1500.00$, además de pagar por toda la superficie del ejido y no solo por 200 ha. Aun así, los entrevistados apreciaron el apoyo recibido del PSAH porque consideraron que mejoraron las condiciones del bosque.

De acuerdo con Porras et al. (2008), los programas de pago por servicios ambientales promovidos por los gobiernos nacionales o locales buscan ser mecanismos temporales de pago que hace el Estado a los dueños de los bosques y selvas, en tanto se forma un mercado por servicios ambientales en donde los consumidores de agua paguen alguna cantidad de dinero a los dueños de los bosques para su conservación que permita mantener la infiltración de agua subterránea y los escurrimientos hasta los cauces superficiales.

Los informantes clave señalaron que la CONAFOR nunca les planteó la posibilidad de crear un mecanismo permanente de mercado donde los consumidores de agua extraída del acuífero pagaran a los

\section{Payments for hydrological environmental services}

The main mechanism for backing from the PSAH toward the ejidos was the transference of economic resources in exchange of two principal conditions: 1) not to perform forest extraction in the properties benefitted; and 2) to carry out conservation works and tasks to improve the ecological conditions of the properties to maintain the plant coverage.

In 2005, the PSAH paid a fee of $\$ 300.00 \mathrm{ha}^{-1}$, which meant an amount of $\$ 60000.00$ annually for the 200 ha in each property benefitted. The money had to be destined to paying for workdays, services and materials necessary to perform conservation works and activities. When asking the ejidatarios what they invested the resources in, the ejido of Tequexquinahuac and San Pablo Ixayoc pointed out that they were destined entirely to the forest conservation actions and in the ejido of San Miguel Tlaixpan, $60 \%$ was destined to conservation actions and $40 \%$ to building the ejido hall.

None of the ejidos destined the money to distribute to ejidatarios, which is why the only form of economic benefit was payment for workdays to carry out conservation works. In the interviews they key informants and the ejidatarios agreed that the fee paid by the PSAH is too low and that it doesn't even cover the costs of giving good maintenance to the forest. The majority agreed that the fee should be at least $\$ 1500.00$, in addition to paying for the whole surface of the ejido and not only for 200 ha. Even so, the interview respondents appreciated the backing received from the PSAH because they considered that the conditions of the forest improved.

According to Porras et al. (2008), the payment from programs for environmental services promoted by the national or local governments seek to be temporary payment mechanisms that the State makes to owners of forests and rainforests, while a market for environmental services is formed where water consumers pay a certain amount of money to the forest owners for their conservation that allows maintaining the infiltration of underground water and runoffs toward superficial channels.

Key informants pointed out that CONAFOR never suggested the possibility of creating a permanent market mechanism where consumers of water extracted from the aquifer would pay the ejidatarios a certain amount for payment of 
ejidatarios alguna cantidad por pago por servicios ambientales hidrológicos provistos por sus bosques. Esto significó que al finalizar los cinco años de apoyos otorgados por el PSAH los ejidos dejaron de percibir ingresos por servicios ambientales.

\section{Obras de conservación, de suelo y agua, realizadas durante el período de apoyo}

En 2005 las reglas de operación del PSAH no contemplaban la implementación del Programa de Mejores Prácticas de Manejo (PMPM). Dentro de los derechos y obligaciones de los beneficiarios del PSAH solo se consideraba "mantener como mínimo la vigilancia del predio", con la finalidad de asegurar la conservación de la misma cobertura forestal que tenía el predio al inicio del apoyo.

El apoyo del PSAH a los tres ejidos inició en 2005, por lo que ninguno de ellos tenía el compromiso u obligación de realizar actividades de conservación o restauración en sus predios. Sin embargo, en los tres casos se hicieron varias actividades para mejorar las condiciones del bosque.

Algunos de los trabajos realizados fueron: reforestaciones, apertura de zanjas trinchera, presas de palos, morillo y piedra acomodada, apertura de brechas cortafuego, acomodo de material vegetal muerto, colocación de letreros, podas y chaponeos, entre otros.

Reforestaciones: La reforestación fue una actividad realizada en los tres ejidos; aunque hubo una variación en el número de hectáreas reforestadas esta diferencia no fue significativa. El ejido con menor superficie reforestada fue San Pablo Ixayoc (15 ha) y la mayor fue la de San Miguel Tlaixpan (30 ha).

Tinas ciega o zanjas trinchera: Se realizaron en los ejidos de San Miguel Tlaixpan y Tequexquinahuac. En el primero estas obras cubrieron una superficie de dos hectáreas. El tamaño de las zanjas fue de dos metros de largo por $0.5 \mathrm{~m}$ de profundidad y $0.4 \mathrm{~m}$ de ancho. En el de Tequexquinahuac se cubrió una superficie total de tres hectáreas, encontrándose zanjas de dos tamaños diferentes, de dos y de cinco metros de largo (Figura 1).

Presas de ramas: Se construyeron solo en los ejidos de Tequexquinahuac y San Pablo Ixayoc, con el objetivo de retener azolves, así como reducir la velocidad de escurrimiento. En total se identificaron cuatro obras de este tipo en el ejido de San Pablo Ixayoc $y$ tres en el de Tequexquinahuac (Figura 2). hydrological environmental services provided by their forests. This meant that at the end of the five years of backing granted by the PSAH the ejidos ceased to obtain income for environmental services.

\section{Conservation works, of soil and water, carried out during the backing period}

In 2005 the operation rules of the PSAH did not contemplate the implementation of the Better Management Practices Program (Programa de Mejores Prácticas de Manejo, PMPM). Within the rights and obligations of the PSAH beneficiaries, it was only considered to "maintain as minimum vigilance of the property", with the aim of ensuring the conservation of the same forest cover that the property had at the beginning of the backing.

Backing of the PSAH to the three ejidos began in 2005, which is why none of them had the

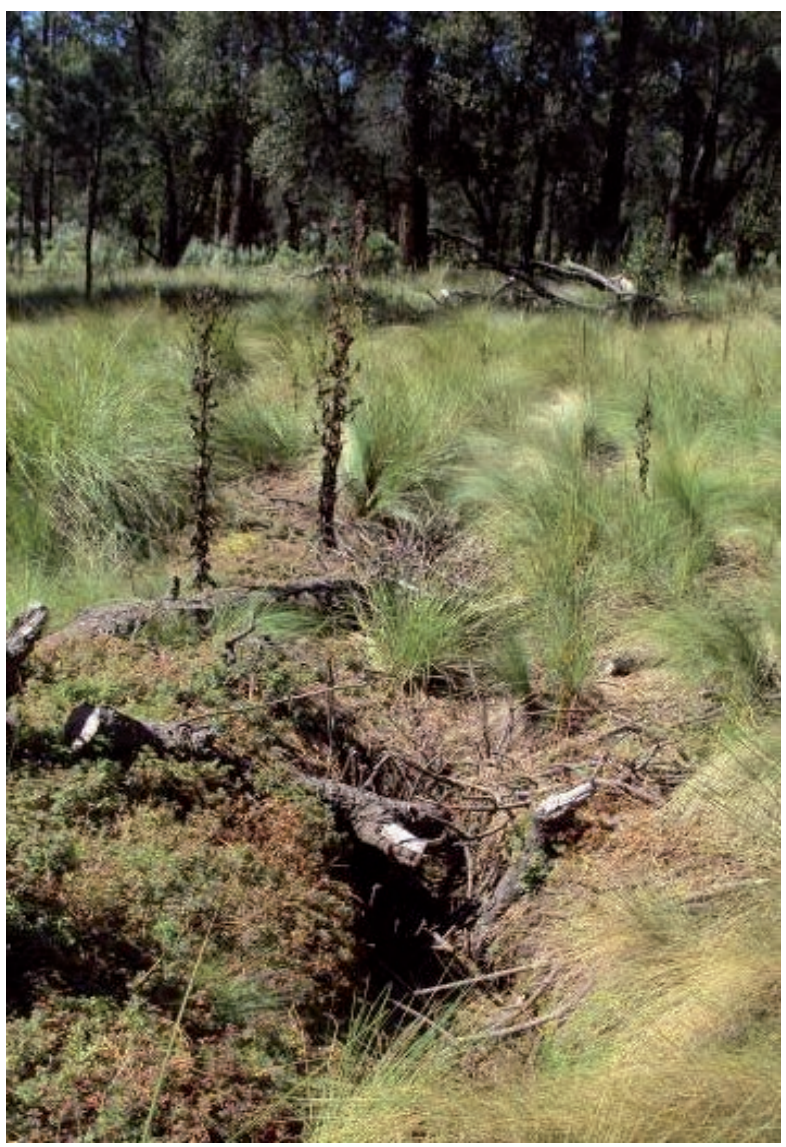

Figura 1. Área de tinas ciegas en el Ejido de Tequexquinahuac. Figure 1. Area of blind tubs in Ejido de Tequexquinahuac. 


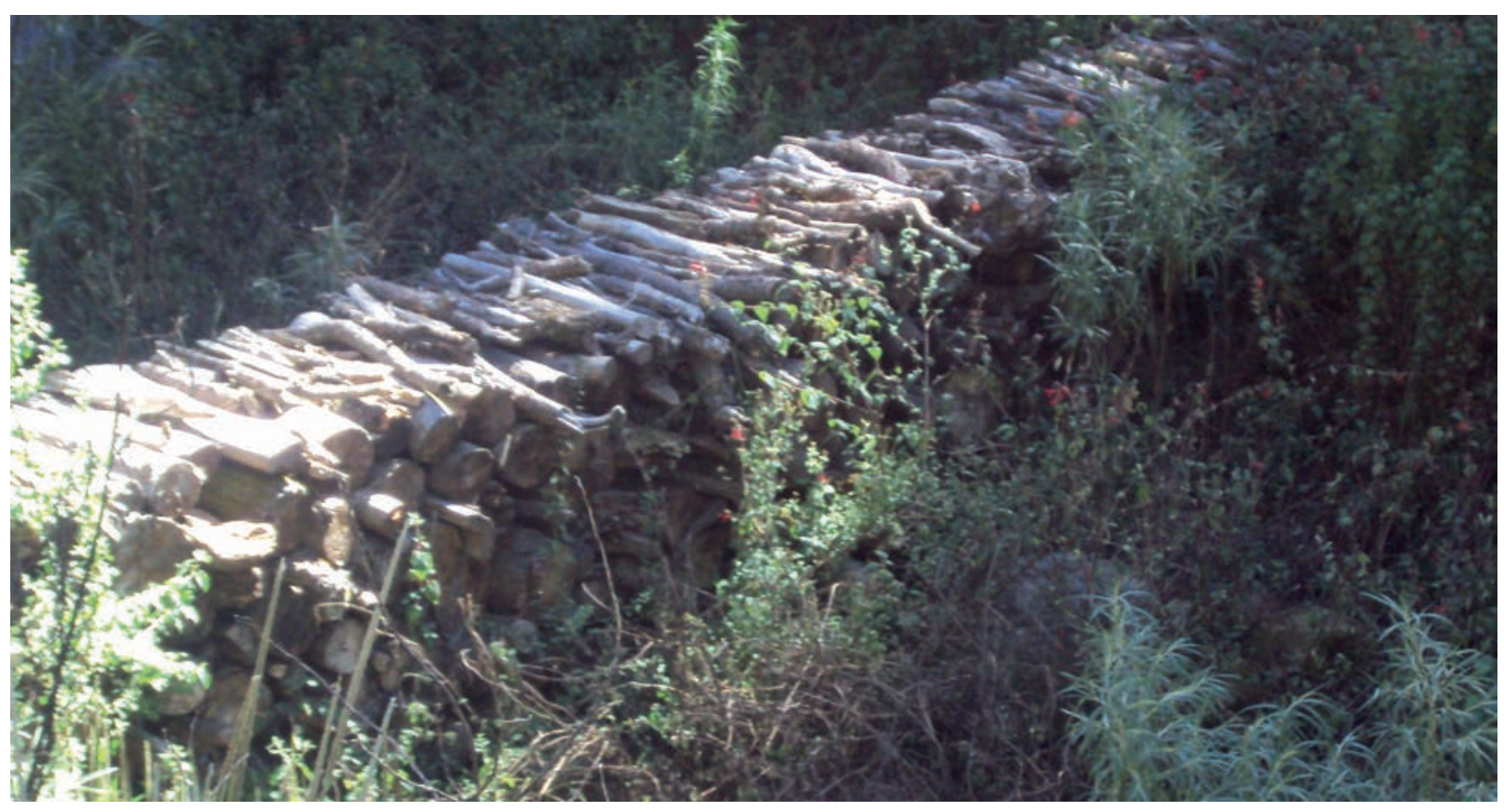

Figura 2. Presa de ramas en el Ejido de Tequexquinahuac. Figure 2. Branch dams in Ejido de Tequexquinahuac.

Presas de morillos: Los ejidos de Tequexquinahuac y San Pablo Ixayoc fueron los únicos que realizaron este tipo de obras de conservación de suelo. En Tequexquinahuac se ubicaron tres presas de este tipo y en San Pablo Ixayoc, cinco.

Presas de piedra acomodada: Este tipo de obras solo se realizó en el ejido de Tequexquinahuac, haciéndose en total tres presas (Figura 3).

Reparación y mantenimiento de caminos: Los tres ejidos invirtieron recursos en este tipo de trabajos. Unieron esfuerzos y recursos para reparar, en forma conjunta, parte del camino principal de acceso al bosque, ya que el beneficio fue colectivo. Sin embargo, el de San Pablo Ixayoc invirtió más recursos en la reparación de caminos secundarios (Figura 4).

Vigilancia: Las actividades de vigilancia fueron cubiertas totalmente por los tres ejidos, sin el apoyo del PSAH, aunque el ejido de San Pablo Ixayoc es el que más sobresalió en esta actividad.

Brigadas contraincendios: Ninguno de los tres ejidos cuenta con una brigada contraincendios permanente, sin embargo, tanto el de Tequexquinahuac como San Pablo Ixayoc están muy bien organizados para combatir los incendios cuando ocurren. Por su parte, San Miguel Tlaixpan no tiene una estrategia definida donde cada brigadista ejecute una función commitment or obligation of performing activities of conservation or restoration in their properties. However, in the three cases several activities were carried out to improve the conditions of the forest.

Some of the works performed were: reforestations, opening ditch trenches, dams with branches, andirons and arranged stones, opening firebreak trails, arrangement of dead plant material, placing signs, pruning and chaponeo, among others.

Reforestations: Reforestation was an activity carried out in the three ejidos; although there was a variation in the number of hectares reforested, this difference was not significant. The ejido with smallest surface reforested was San Pablo Ixayoc (15 ha) and the largest was San Miguel Tlaixpan (30 ha).

Blind tubs or ditch trenches: They were made in the ejidos of San Miguel Tlaixpan and Tequexquinahuac. In the first these works covered a surface of two hectares. The size of the ditches was two meters long by $0.5 \mathrm{~m}$ deep, and 0.4 wide. In Tequexquinahuac a total surface of three hectares was covered, with presence of ditches of two different sizes, two and five meters long (Figure 1).

Branch dams: They were built only in the ejidos of Tequexquinahuac and San Pablo Ixayoc, with the objective of retaining sediments, as well as reducing 


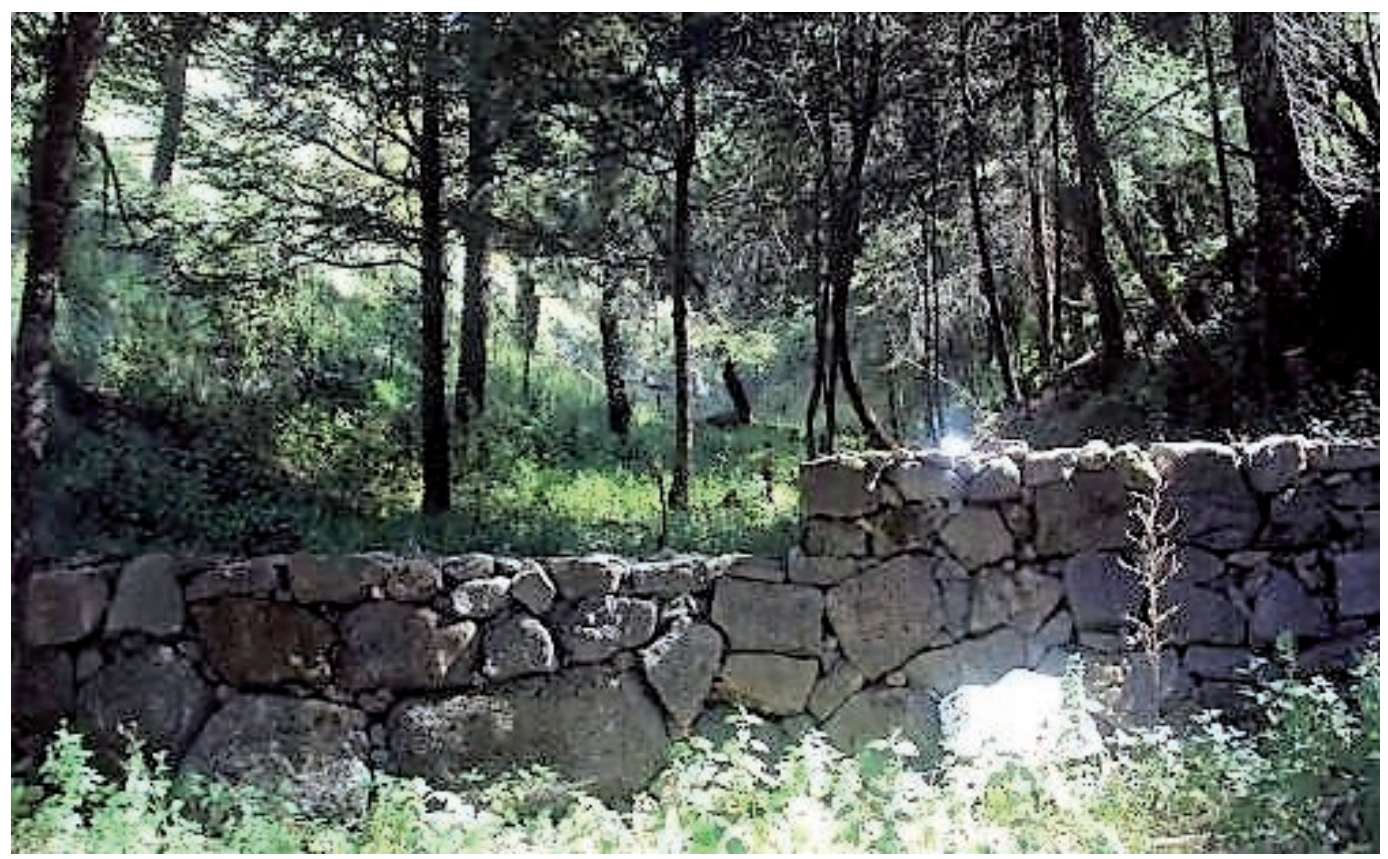

Figura 3. Presa de piedra acomodada en el Ejido de Tequexquinahuac.

Figure 3. Arranged stone dam in Ejido de Tequexquinahuac.

para combatir este tipo de siniestros, por lo que piden el apoyo a los ejidos vecinos cuando ha llegado a suceder algún incendio. the speed of runoff. In total, four works of this type were identified in the ejido of San Pablo Ixayoc and three in Tequexquinahuac (Figure 2).

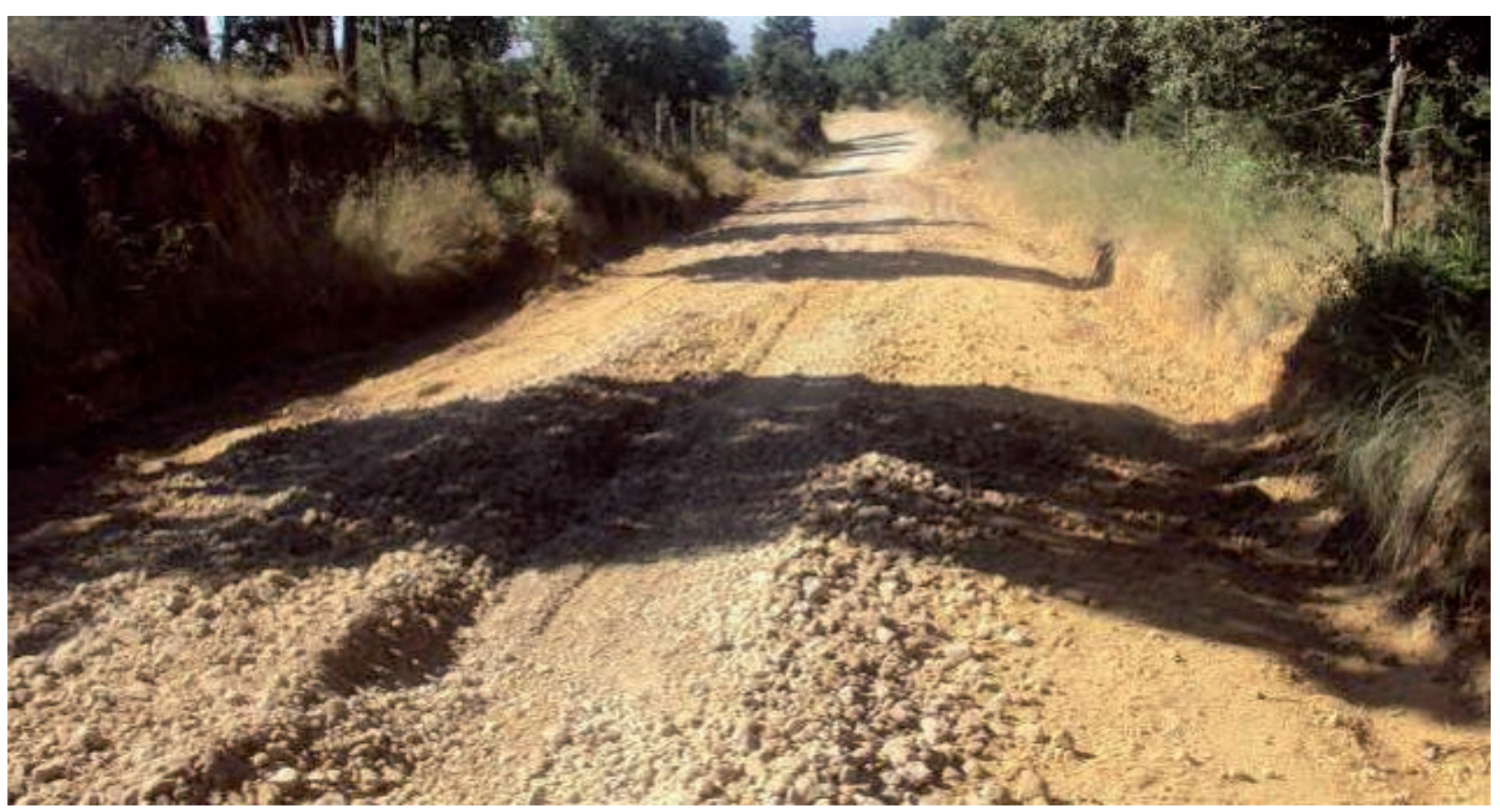

Figura 4. Mantenimiento del camino principal de acceso al bosque.

Figure 4. Maintenance of the main access road to the forest. 


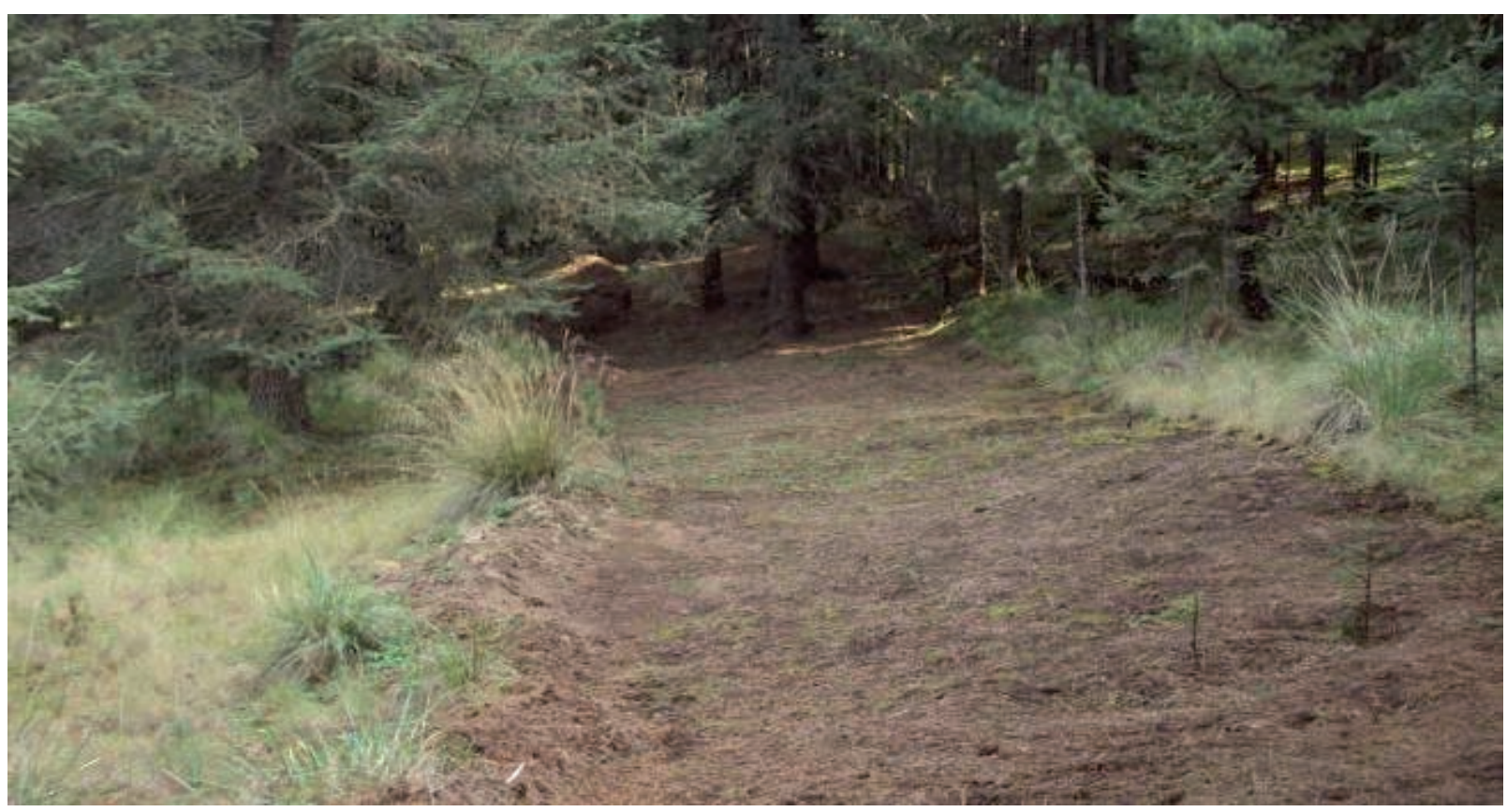

Figura 5. Apertura de brecha cortafuego en el Ejido San Miguel Tlaixpan.

Figure 5. Opening of firebreak trails in Ejido San Miguel Tlaixpan.

Apertura y mantenimiento de brechas cortafuego: Los tres ejidos ya cuentan con un Programa de Manejo Forestal, incluyendo los predios apoyados. Esto significa que las brechas cortafuego ya estaban trazadas con anterioridad al PSAH y solo se les dio mantenimiento. Únicamente el ejido de San Miguel Tlaixpan abrió una brecha nueva (de 50 metros de largo) (Figura 5).

Colocación de letreros: A pesar de que no era obligatorio, los tres ejidos colocaron más de dos letreros en cada predio apoyado (de 5 a 20 letreros) (Figura 6).

\section{Condición de los predios forestales una vez concluido el apoyo del PSAH}

En las entrevistas, los ejidatarios y los informantes clave manifestaron que los predios beneficiados por el PSAH están en mejores condiciones actualmente que al inicio del apoyo del programa porque se realizaron las obras de mejoramiento del bosque con recursos del programa. En los recorridos de campo se observó que el bosque de los tres predios ejidales tiene una apariencia vigorosa, sana y agradable como resultado del buen cuidado y manejo que han hecho los ejidatarios. Por ello, los predios
Andiron dams: The ejidos of Tequexquinahuac and San Pablo Ixayoc were the only ones that carried out this type of works for soil conservation. In Tequexquinahuac, three dams of this type were found, and five in San Pablo Ixayoc.

Arranged stone dams: This type of works was only performed in the ejido of Tequexquinahuac, building in total three dams (Figure 3).

Repair and maintenance of paths: The three ejidos invested resources in this type of works. They joined efforts and resources to repair, together, part of the main access road to the forest, since the benefit was collective. However, San Pablo Ixayoc invested more resources in the repair of secondary roads (Figure 4).

Vigilance: The vigilance activities were covered totally by the three ejidos, without the support of the PSAH, although the ejido of San Pablo Ixayoc is the one that stood out most in this activity.

Firefighting brigades: None of the three ejidos has a permanent firefighting brigade; however, both Tequexquinahuac and San Pablo Ixayoc are very well organized to combat the fires when they happen. In its turn, San Miguel Tlaixpan does not have a defined strategy where each brigade member executes a function to combat this type of disasters, which is 


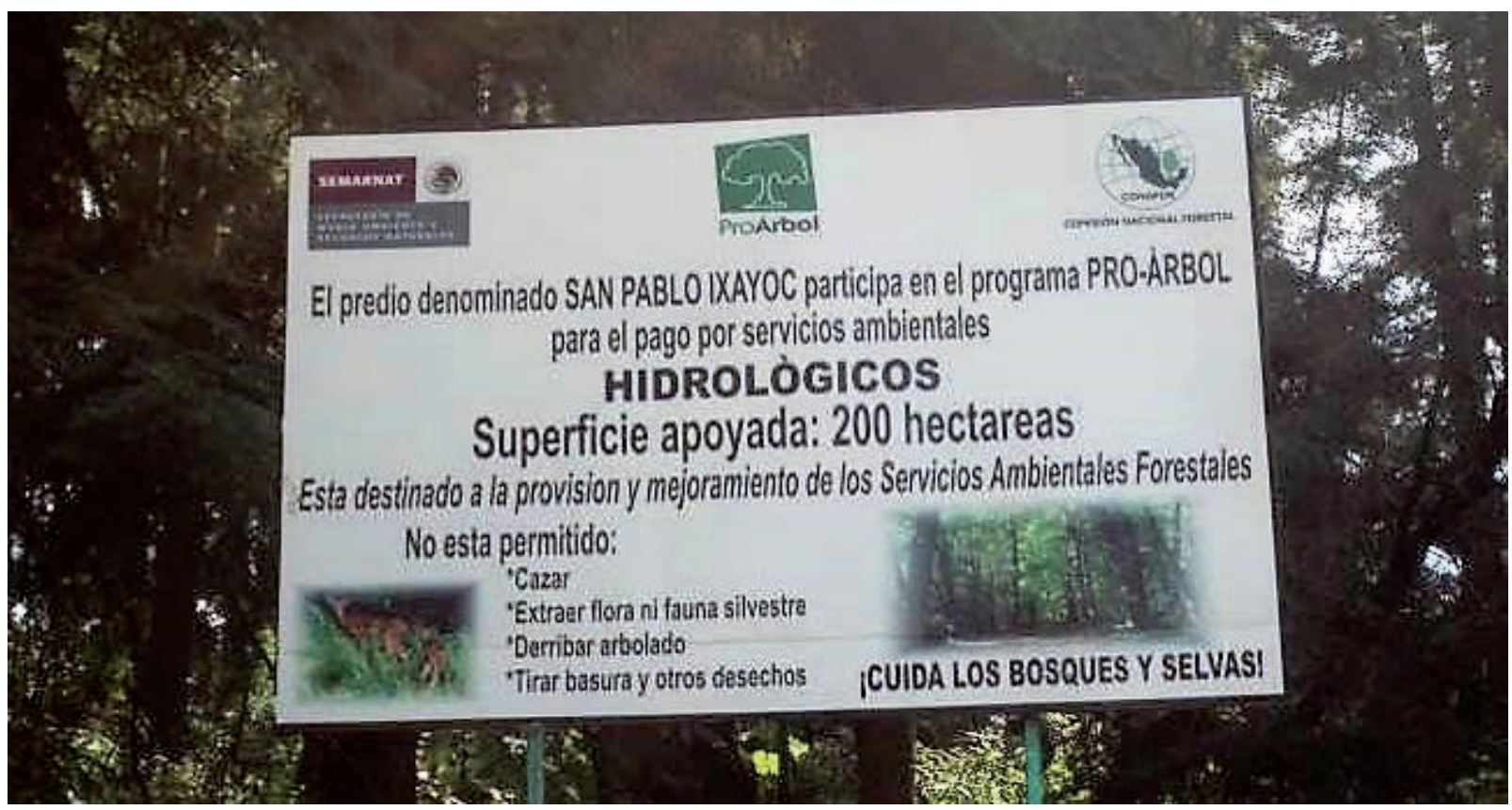

Figura 6. Letrero colocado en el predio del Ejido San Pablo Ixayoc Figure 6. Sign placed on the property in Ejido San Pablo Ixayoc.

cumplen adecuadamente con la provisión de servicios ambientales hidrológicos (Figura 7).

Todos los entrevistados coincidieron en que los predios forestales apoyados por el PSAH están en mejores condiciones que antes de recibir los apoyos y señalaron tres razones: 1) en los predios beneficiados no se hicieron aprovechamientos maderables durante cinco años; 2) los ejidos cumplieron los compromisos adquiridos por reglas de operación del PSAH porque realizaron obras y actividades de conservación para mejorar las condiciones del bosque (reforestaciones, obras de conservación de suelo y agua, prevención de incendios, entre otras) con los recursos del PSAH, y 3) no se presentaron siniestros graves (como la presencia de incendios, plagas o enfermedades) o problemas de tala clandestina en los tres predios apoyados.

A dos ańos de haber terminado los pagos por servicios ambientales de la CONAFOR a los tres ejidos, los ejidatarios continúan realizando algunas actividades de mejora. Por ejemplo, se constató en campo que en el de Tequexquinahuac se han hecho chaponeos y podas; en San Miguel Tlaixpan, reforestaciones y mantenimiento de brechas cortafuego; y en San Pablo Ixayoc se sigue realizando la vigilancia constante.

Después de concluir su participación en el PSAH actualmente, solo uno de los ejidos sigue recibiendo why they have asked for support from neighboring ejidos when a fire has taken place.

Opening and maintaining firebreak trails: The three ejidos already have a Forest Management Program, including the properties supported. This means that the firebreak trails had been traced prior to the PSAH and they only gave them maintenance. Only the ejido of San Miguel Tlaixpan opened a new trail (50 meters long) (Figure 5).

Placing signs: Although it was not mandatory, the three ejidos placed more than two signs in each property supported (5 to 20 signs) (Figure 6).

\section{Condition of the forest properties once backing from the PSAH concluded}

In the interviews, the ejidatarios and the key informants manifested that the properties benefitted by the PSAH are in better conditions today than at the beginning of the program backing because works to improve the forest were carried out with resources from the program. In the field visits it was observed that the forests in the three ejido properties have a vigorous, healthy and pleasant appearance as a result of the good care and management that ejidatarios have performed. Therefore, the properties 


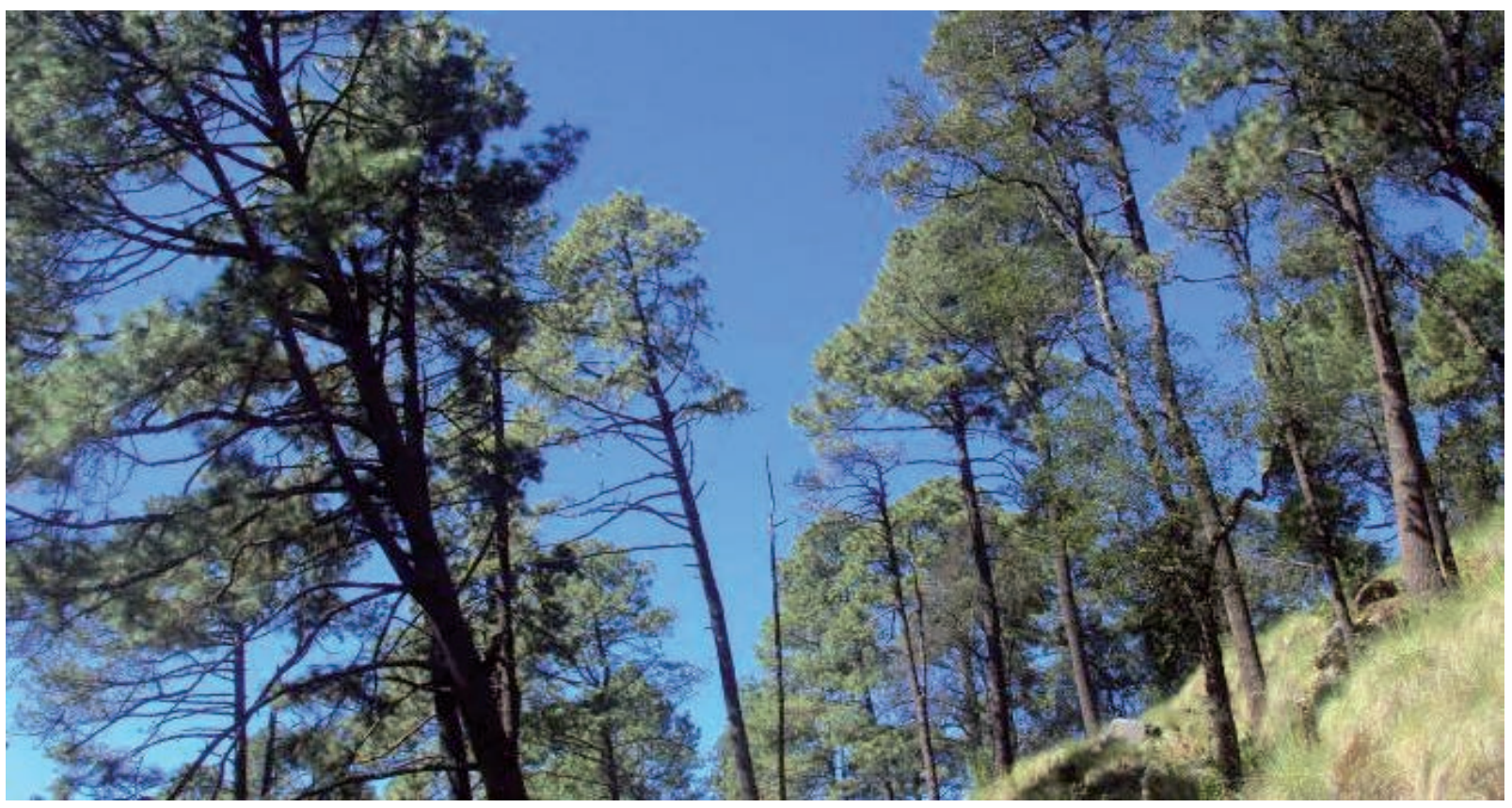

Figura 7. Bosque de pino (Pinus spp.) del Ejido Tequexquinahuac. Figure 7. Pine forest (Pinus spp.) in Ejido Tequexquinahuac.

apoyos de la CONAFOR y los otros dos participan en el programa de Pago por Servicios Ambientales Hidrológicos del Gobierno del Estado de México. Sin embargo, los tres están participando con predios diferentes a los apoyados por el PSAH de 2005 a 2010. Esto indica que han sabido aprovechar los apoyos disponibles en distintos niveles de gobierno (federal y estatal), lo cual es motivado porque los pagos por servicios ambientales que otorga el PSAH fueron muy pocos.

Los predios de los tres ejidos forestales participantes en el PSAH (2005-2010) actualmente tienen el siguiente uso:

El predio del ejido Tequexquinahuac está siendo aprovechado bajo el Programa de Manejo Forestal porque ya concluyó su tiempo de "reposo" o "descanso", así como su participación en el programa. El interés actual del ejido sobre este es hacer aprovechamiento maderable.

El predio del ejido de San Miguel Tlaixpan fue decretado "área de reserva", con el fin de que se conserve y no se hagan aprovechamientos maderables. La decisión del ejido fue basada en que este predio se localiza a una distancia lejana del núcleo ejidal, por lo cual siempre ha sido una de las áreas del bosque mejor conservada y se encuentra en el perímetro de fulfill adequately the provision of hydrological environmental services (Figure 7).

All the interview respondents agreed that the forest properties supported by the PSAH are in better conditions than before receiving the backing and they pointed to three reasons: 1 ) in the properties benefitted no timber extraction was done for five years; 2) the ejidos fulfilled the commitments acquired through operation rules of the PSAH because they carried out conservation works and activities to improve the forest conditions (reforestations, works for soil and water conservation, prevention of fires, among others) with the PSAH resources; and 3) no serious disasters took place (such as the presence of fires, pests or diseases), or problems with clandestine felling in the three periods supported.

Two years after having concluded with the payments for environmental services from CONAFOR to the three ejidos, the ejidatarios continue to perform some improvement activities. For example, it was observed in the field that in Tequexquinahuac chaponeos and pruning were performed; in San Miguel Tlaixpan, reforestations and maintenance of firebreak trails; and in San Pablo Ixayoc constant vigilance is still being performed.

After concluding their participation in the PSAH, currently only one of the ejidos continues 
lo que es el Parque Nacional Izta-Popo, que es un Área Natural Protegida. El predio actualmente está en veda y está siendo vigilado por los ejidatarios, aunque se han autorizado aprovechamientos de lama y musgo.

Por último, el predio del Ejido de San Pablo Ixayoc está en espera de ser aprovechado, una vez que les sea aprobado el nuevo Plan de Manejo del ejido porque el anterior terminó su vigencia en 2010.

\section{Discusión}

La línea de política pública del programa pago por servicios ambientales fue focalizar, durante la primera etapa, los recursos federales donde puede hacer una diferencia mayor. Es decir, en las áreas forestales que no generan ingresos para sus propietarios y que por esta razón se considera que pueden estar en mayor riesgo de deforestación por cambio de uso de suelo (González-Guillén et al., 2006). En los ejidos estudiados esta premisa no se cumplió ya que en los tres casos los predios participantes no eran las áreas en mayor riesgo de deforestación ni eran áreas abandonadas.

El PSAH parte del supuesto de que la no intervención con fines de aprovechamiento maderable en las áreas de bosque es siempre una estrategia suficiente para asegurar su conservación. Bajo esta premisa las reglas de operación del PSAH no consideran el apoyo a predios con aprovechamiento maderable, sino que solo se consideran aquellos que estén dentro de un programa de manejo que sean "áreas en recuperación o reposo". A este enfoque se le llama "Conservación Pasiva", debido a que se considera que el bosque se va a conservar sin tocarlo o, en el mejor de los casos, realizando algunas obras y labores de conservación.

La política forestal nacional no apoya la idea de que "un bosque o un predio que esté siendo aprovechando es capaz de brindar los mismos beneficios ambientales que uno que no se toque". Esto es, que la "Conservación Activa" o bajo buen manejo no es aceptable para el PSAH de la CONAFOR.

Taylor (2013) indica que la deforestación es un factor que promueve el cambio climático. El impacto de estos efectos en la recarga de los acuíferos no está resuelto del todo; sin embargo, evidencias previas (Tague y Grant, 2009; Sultana y Coulibaly, 2011) indican que los cambios en los régimen del deshielo tienden a reducir la duración y magnitud to receive backing from CONAFOR and the other two participate in the Payment for Hydrological Environmental Services of the Estado de México government. However, the three are participating with properties different from the ones backed by the PSAH from 2005 to 2010. This indicates that they have been able to take advantage of the backing available in different levels of government (federal and state), which is motivated because the payments for environmental services that the PSAH grants were very scarce.

The properties from the three forest ejidos that participated in the PSAH (2005-2010) currently have the following use:

The property in the ejido of Tequexquinahuac is being exploited under the Forest Management Program because its "resting" time has concluded, as well as its participation in the program. Today's interest in the ejido is to carry out timber extraction.

The property in the ejido of San Miguel Tlaixpan was declared "reserve area", with the aim of conserving it and not making timber extractions. The decision of the ejido was based on the fact that this property is located at a distance far from the ejido nucleus, which is why it has always been one of the areas of the forest best conserved and is found on the perimeter of the Izta-Popo National Park, which is a Natural Protected Area. The property is currently in closed season and is being watched by the ejidatarios, although extraction of moss and lama has been authorized.

Lastly, the property in the ejido of San Pablo Ixayoc is waiting to be exploited, once the new Management Plan in the ejido is approved, because the last one's validity ended in 2010 .

\section{DisCUSSION}

The public policy line of the program for payment of environmental services was to find, during the first stage, the federal resources where it can make a greater difference. That is, in forest areas that do not generate income for their owners and which for that reason are considered to be in greater danger of deforestation from change of land use (González-Guillén et al., 2006). In the ejidos studied this premise was not fulfilled since in the three cases the participating properties were not the areas at higher risk of deforestation, nor were they abandoned areas. 
de la recarga. Una disminución considerable en los niveles del manto freático en Texcoco puede hacer insuficiente el agua para satisfacer los requerimientos domésticos y agrícolas, y para mantener funciones ecológicas básicas en un mediano plazo.

Un bosque bien manejado no debe demeritar la calidad y cantidad de provisión de agua y otros servicios ambientales. En un estudio realizado por NávarCháidez (2011) se encontró que el manejo de los bosques para su conservación y restauración mediante diversas prácticas silvícolas tendientes a aumentar la diversidad biológica y la diversidad estructural permiten aumentar la productividad de las comunidades templadas de los ecosistemas forestales y hacerlos más aptos para la oferta de servicios ambientales, como la provisión del recurso hídrico.

Sin embargo, aun cuando en muchas regiones del país el aprovechamiento forestal se asocia directamente a las experiencias más exitosas de conservación y desarrollo de los bosques, combinar provisión de servicios ambientales con el aprovechamiento forestal no es algo para lo que México este aun preparado. Por tal motivo, los tres predios ejidales estudiados fueron aceptados para participar en el PSAH porque su estatus era "recuperación o reposo" en el plan de manejo de los ejidos.

De acuerdo con la información obtenida en la investigación, una de las principales razones para participar en el PSAH no fue solo "cuidar y conservar el bosque", sino que los ejidos aceptaron no hacer aprovechamientos maderables durante los cinco años de participación; solo se iban a mantener en descanso. Esto les dio una opción de ingreso a los ejidos por predios que no querían o no podían aprovechar su madera.

Las reglas de operación actuales contemplan que para predios con programa de manejo forestal maderable vigente solo serán elegibles los polígonos que se encuentren fuera de las áreas de corta autorizadas. Son elegibles las áreas de corta solo cuando el solicitante demuestre que cuenta con la certificación de buen manejo de bosques (SEMARNAT, 2011).

Esto implica mayores requisitos para los dueños del bosque, ya que no solo basta con contar con un plan de manejo forestal, sino estar dentro de un padrón de la CONAFOR donde se ha certificado el buen manejo forestal. Esto indica que para la CONAFOR el aprovechamiento y la provisión de servicios ambientales no son totalmente compatibles, lo que
The PSAN stems from the assumption that nonintervention with the aim of timber extraction in forest areas is always a sufficient strategy to ensure their conservation. Under this premise the operation rules of the PSAH do not consider backing for properties with timber extraction, but rather only consider those that are within a management program that are "areas in recovery or rest". This approach is called "Passive Conservation", because it is considered that the forest will be conserved without touching it or, in the best case scenario, by performing some conservation works and tasks.

The national forest policy does not support the idea that "a forest or property that is being exploited is capable of providing the same environmental benefits that one that is not touched". That is, "Active Conservation" or good management is not acceptable for the CONAFOR's PSAH.

Taylor (2013) indicates that deforestation is a factor that promotes climate change. The impact of these effects on the aquifer reload is not entirely understood; however, prior evidence (Tague and Grant, 2009; Sultana and Coulibaly, 2011) indicate that changes in the ice thawing regime tend to reduce the duration and magnitude of the reload. A considerable decrease in the water table levels in Texcoco can result in insufficient water to satisfy the domestic and agricultural requirements, and to maintain the basic ecological functions in a medium term.

A well-managed forest should not belittle the quality and quantity of provision of water and other environmental services. In a study carried out by Návar-Cháidez (2011) it was found that the forest management for their conservation and restoration through various forestry practices that tend to increase biological diversity and the structural diversity allow increasing the productivity of the temperate communities from forest ecosystems and making them more apt for the offer of environmental services, such as the provision of the water resource.

However, even when in many regions of the country forest exploitation is associated directly to the most successful experiences of conservation and development of forests, combining the provision of environmental services with forest exploitation is not something for which México is yet prepared. Therefore, the three ejido properties studied were accepted to participate in the PSAH because their 
obliga a los dueños del bosque a conservarlo solo por el período en el que reciben apoyo del programa y optar por volver a hacer aprovechamiento maderable cuando ya no tengan compromisos de conservación y permanencia.

Los investigadores que han estudiado los esquemas de PSA (Porras et al., 2008) diseñados actualmente, han encontrado una clara tendencia hacia eliminar los esquemas de prohibición del uso de los recursos y en su lugar generar otros que compensen el buen manejo (Madrid-Ramírez, 2011), o sea, se busca promover el enfoque de "Conservación Activa" y el pago por servicios ambientales por buen manejo del bosque.

Sin duda, la tendencia futura y la mejor opción de los esquemas de PSA es compensar el buen manejo (conservación activa) y no pagar solo por conservar o reforestar (conservación pasiva), sin usar los recursos naturales disponibles, ya que estos son los insumos de cualquier actividad económica desarrollada por el hombre y es casi imposible dejarlos de utilizar.

En lo que respecta a los trabajos realizados en campo para conservar y mejorar las condiciones del bosque, en los recorridos de campo se verificó que las obras de conservación fueron de buena calidad y cumplieron con los objetivos específicos para los que fueron diseñados, como el control de la erosión hídrica, control de azolves, retención de humedad, protección, etcétera. En conjunto, también cumplieron con el objetivo principal, que fue mejorar las condiciones del bosque aunque de forma limitada.

Los recorridos de campo fueron una herramienta valiosa para complementar la información obtenida en las entrevistas. Gracias a ellos se pudo corroborar mucha de la información proporcionada por los ejidatarios y personal técnico sobre las condiciones de los predios apoyados por el PSAH.

En el caso de estudio, el PSTF y los ejidatarios entrevistados coincidieron en que las condiciones actuales de los predios apoyados son mejores que antes de participar en el programa. Estas mejoras se basan en tres razones fundamentales 1) en los predios beneficiados no se hicieron aprovechamientos maderables durante el tiempo de apoyo del PSAH; 2) los ejidos cumplieron los compromisos adquiridos por reglas de operación del PSAH porque realizaron obras y actividades de conservación para mejorar las condiciones del bosque (reforestaciones, obras de conservación de suelo y agua, prevención de incendios, entre otras) status was "recovery or rest" in the ejidos' management plan.

According to the information obtained in the research, one of the main reasons to participate in the PSAH was not only "to care and conserve the forest", but rather the ejidos accepted to stop timber extraction during the five years of participation; they were only going to be kept at rest. This gave them the option of income for the ejidos for properties that they did not want to or could not extract timber from.

The current operation rules contemplate that for properties with timber-yielding forest management programs in place, only the polygons that are outside the areas with authorized felling would be eligible. The felling areas are only eligible when the petitioner demonstrates that he has the certification of good forest management (SEMARNAT, 2011).

This implies more requirements for the forest owners, since it is not enough to have just a forest management plan, but rather they must be in a CONAFOR registry where good forest management has been certified. This indicates that for CONAFOR the exploitation and the provision of environmental services are not entirely compatible, forcing the forest owners to conserve it only for the period when they receive backing from the program, and to opt to returning to timber extraction when they do not have commitments for conservation and permanence.

The researchers who have studied the PSA plans (Porras et al., 2008) currently designed, have found a clear trend toward eliminating the prohibition schemes for the use of resources and in their place generating others that compensate good management (Madrid-Ramírez, 2011); that is, there is an intention to promote the approach of "Active Conservation" and the payment of environmental services for good forest management.

Without a doubt, the future trend and best option of PSA plans is to compensate good management (active conservation) and not to just pay for conserving or reforesting (passive conservation), without making use of the natural resources available, since these are the inputs of any economic activity developed by humans and it is nearly impossible to leave them without using.

With regard to the works carried out in the field to conserve and improve the forest conditions, in the field visits it was verified that the conservation 
con los recursos del PSAH; y 3) no se presentaron siniestros graves (como la presencia de incendios, plagas o enfermedades) o problemas de tala clandestina.

Los ejidos deciden aprovechar nuevamente sus predios porque el dinero que reciben del PSAH es muy poco y solo alcanzan a pagar algunas actividades y obras de conservación que no son suficientes para darle los cuidados y mantenimiento necesario al bosque. Ninguno de los recursos otorgados por el PSAH fue repartido directamente para el bolsillo de los ejidatarios. Ellos solamente recibieron el pago de jornales para realizar las labores de conservación en los predios beneficiados. Aquí la disyuntiva de los ejidatarios es conservar sin recibir beneficios económicos significativos o usar estos predios con vocación forestal para aprovechar la madera y percibir ingresos.

Lamentablemente no se tiene información precisa, ni evidencias fotográficas, de cómo se encontraban los predios antes de participar en el programa. Solo se cuenta con la información recabada del PSTF y de los ejidatarios sobre tales condiciones y con lo que se observó en los recorridos de campo. Sin embargo, es indiscutible que la realización de algunas obras de conservación de suelo y agua, reforestaciones o alguna otra actividad impacta favorablemente en beneficio del bosque.

Un dato importante que revela la evaluación del PSAH 2003-2007 es que $36 \%$ de los beneficiarios coinciden en que, de no existir el PSAH, usarían su terreno con fines agropecuarios y solo un tercio de ellos mantendría su uso forestal (González-Guillén et al., 2008).

Las áreas beneficiadas corren el riesgo de ser deforestadas por una decisión basada en factores de mercado y necesidades económicas, a pesar de las restricciones legales que existen. La situación actual de los predios beneficiados por el PSAH en los tres ejidos estudiados es la siguiente: 1) El predio del Ejido de Tequexquinahuac está siendo aprovechado bajo el Programa de Manejo del Ejido; 2) el predio del Ejido de San Pablo Ixayoc está en espera de ser aprovechado una vez que se apruebe el Programa de Manejo del ejido; y 3) el predio del Ejido San Miguel Tlaixpan fue decretada área de reserva en veda y solo se permiten pequeñas extracciones de lama, musgo y madera plagada o enferma. Esta última es una de las áreas mejor conservadas dentro del Parque Nacional Izta-Popo.

Después de conocer el estado actual que guardan los predios apoyados se puede concluir que el works were of good quality and fulfilled the specific objectives for which they were designed, such as control of hydric erosion, sediment control, moisture retention, protection, etc. As a whole, they also fulfilled the main objective, which was to improve the forest conditions even if in a limited way.

The field visits were a valuable tool to complement the information obtained in the interviews. Thanks to them, much of the information provided by the ejidatarios and the technical staff about the conditions of the properties backed by the PSAH could be confirmed.

In the case study, the PSTF and the ejidatarios interviewed agreed that the current conditions of the properties supported are better than before participating in the program. These improvements are based on three fundamental reasons: 1) in the properties benefitted no timber extractions were made during the time of the PSAH backing; 2) the ejidos complied with the commitments acquired through the operation rules of the PSAH because they performed conservation works and activities to improve the conditions of the forest (reforestations, conservation works for soil and water, prevention of fires, among others) with the PSAH resources; and 3) no serious disasters took place (such as the presence of fires, pests or diseases) or problems with clandestine felling.

The ejidos decided to take advantage again of their properties because the money they received from the PSAH is very little and they can only pay for some conservation activities and works that are not sufficient to give the forest the necessary care and maintenance. None of the resources granted by the PSAH were forked out directly to the ejidatarios. They only received payment for workdays to carry out the conservation tasks in the properties benefitted. Here the dilemma of the ejidatarios is to conserve without receiving significant economic benefits or to use these properties with forestry use to extract timber and receive incomes.

Regretfully there is no precise information, or photographic evidence, of how the properties were before participating in the program. There is only the information gathered by the PSTF and the ejidatarios regarding the conditions and what was observed in the field visits. However, it is undeniable that performing some of the conservation works for soil and water, reforestations, or some other activity impacts favorably in benefit of the forest. 
problema no es tan grave, comparado con los pronósticos que se tenían respecto al futuro de los bosques: abandono, deforestación o cambio de uso de suelo; en ninguno de los tres casos sucedió esto.

\section{ConClusiones}

En 2005 el PSAH tenía un enfoque de "conservación pasiva" por lo que solo admitió predios considerados "en reposo" en el Plan de Manejo de los tres ejidos estudiados, aunque no eran los que corrían más riesgo de ser deforestados. Se ha demostrado en otros estudios que un predio forestal bien manejado puede proveer de la misma o mayor cantidad y calidad de servicios ambientales que un predio en reposo.

Los estudiados están en mejores condiciones después de haber participado en el PSAH de 2005 a 2010 por tres motivos: 1) eran predios no aprovechados porque tenían estatus de "en reposo" en el plan de manejo ejidal; 2) los ejidos cumplieron en gran medida los compromisos con el PSAH al realizar obras y actividades de conservación con recursos del PSAH; y 3) no hubo siniestros importantes en el período (plagas, incendios u otros problemas).

Los pagos por servicios ambientales otorgados por el PSAH fueron muy reducidos, lo que resultó poco atractivo para los ejidos, especialmente después de haber invertido una parte importante en las obras de conservación y no destinar nada a beneficiar económicamente a los ejidatarios.

Es urgente que el PSAH se convierta en un esquema rentable para los productores y que más allá de los cinco años de apoyo les garantice continuar percibiendo un ingreso para la conservación de sus bosques; de lo contrario, no existe ninguna garantía de que estos predios sigan proveyendo los servicios ambientales que a la fecha brindan.

La participación de predios ejidales en el PSAH no garantiza que se vayan a conservar en el largo plazo porque el PSAH no contribuyó a crear un mecanismo local permanente de pagos por servicios ambientales. A pesar de ello, los ejidos siguen realizando actividades de conservación en los predios.

\section{Notas}

${ }^{1}$ http://www.edomex.gob.mx/legistelfon/doc/pdf/ bdo/bdo101.pdf
An important piece of data that reveals the PSAH 2003-2007 evaluation is that $36 \%$ of the beneficiaries agree that if the PSAH did not exist, they would use their land for agricultural and livestock purposes, and only a third of them would keep its forest use (González-Guillén et al., 2008).

The areas benefitted are at risk of being deforested because of a decision based on market factors and economic needs, despite the legal restrictions in place. The current situation of the properties benefitted by the PSAH in the three ejidos studies is the following: 1) The property in Ejido de Tequexquinahuac is being exploited under the Ejido's Management Plan; 2) the property in Ejido de San Pablo Ixayoc is waiting to be exploited once the ejido's Management Program is approved; and 3) the property in Ejido San Miguel Tlaixpan was declared a reserve area in closed season, and only small-scale extraction of moss, lama, and diseased wood is allowed. The latter is one of the areas that are best conserved within the Izta-Popo National Park.

After understanding the current state that the properties supported have, it can be concluded that the problem is not so serious, compared with the predictions there were regarding the future of forests: abandonment, deforestation, or change in land use. This did not happen in any of the three cases.

\section{Conclusions}

In 2005 the PSAH had an approach of "passive conservation", which is why it only admitted properties considered "at rest" in the Management Plan of the three ejidos studied, even when they were not the ones at highest risk of being deforested. It has been shown in other studies that a well-managed forest property can provide the same or greater quantity and quality of environmental services that a property at rest.

The properties studied are in better conditions after having participated in the PSAH from 2005 to 2010, because of three reasons: 1 ) they were properties that were not exploited because they had the status of "at rest" in the ejido's management plan; 2) the ejidos complied to a high degree with the commitments made with the PSAH when performing conservation works and activities with resources from the PSAH; and 3) there were no serious disasters in the period (pests, fires, or other problems). 


\section{Literatura Citada}

Allan, Richard P., y Brian J. Soden. 2008. Atmospheric warming and the amplification of precipitation extremes. Science. Vol. 321. September 2008. pp: 1481-1484.

Bates, Bryson, Zbigniew W. Kundzewicz, Shaohong Wu, y Jean Palutikof. 2008. Climate Change and Water. Technical Paper of the Intergovernmental Panel on Climate Change. IPCC Secretariat. United Nations Environmental Program (UNEP). Ginebra, Suiza. 220 p.

CONAFOR. 2011. Panorámica sobre REDD+ en México. Taller sobre estimación de los costos de oportunidad y costos de implementación para el proceso de planificación nacional. Comisión Nacional Forestal. Unidad de Asuntos Internacionales y Fomento Financiero. [En línea] <http://www.forestcarbonpartnership.org/fcp/sites/forestcarbonpartnership. org/files/Documents/PDF/July2012/04-REDD\%2B\%20 en\%20Mexico\%20-\%20J.A.Alanis\%20et\%20al.pdf> [Consultado el 15 de enero de 2013].

Escobar, Samuel, y Oscar Palacios. 2012. Análisis de la sobreexplotación del acuífero Texcoco, México. Tecnología y Ciencias del Agua. ART-2012-02-05. Abril-junio 2012.

González-Guillén, Manuel. 2006. Evaluación del Programa de Pago de Servicios Ambientales Hidrológicos (PSAH): Ejercicio fiscal 2005. Colegio de Postgraduados y Comisión Nacional Forestal. México. 170 p.

González Guillén, Manuel. 2008. Evaluación externa de los apoyos de los servicios ambientales: Ejercicio fiscal 2007. Evaluación de impactos. Colegio de Postgraduados y Comisión Nacional Forestal. México. 231 p.

Kawulich, Barbara B. 2005. La observación participante como método de recolección de datos. Forum Qualitative Sozialforschung / Forum: Qualitative Social Research [On-line Journal], 6(2), Art. 43, Disponible en: <http://nbn-resolving. de/urn:nbn:de:0114-fqs0502430>. [Consultado el 26 de enero de 2012]

López-Morales, C. 2012. Valoración de servicios hidrológicos por costo de reemplazo: Análisis de escenarios para el Bosque de Agua. Dirección General de Investigación en Ordenamiento Ecológico y Conservación de Ecosistemas, Instituto Nacional de Ecología. México, D.F. Disponible en: <http:// ine.gob.mx/descargas/dgioece/doc_bosque_de_agua.pdf>. [Consultado el 10 de enero de 2013].

Madrid-Ramírez, Lucia. 2011. Los pagos pos servicios Ambientales Hidrológicos: más allá de la conservación pasiva de los bosques. Conservación Ambiental. Vol. 3. Núm. 2. pp: 52-58.

Montes, C., y O. Sala. 2007. La Evaluación de los Ecosistemas del Milenio. Las relaciones entre el funcionamiento de los ecosistemas y el bienestar humano. Ecosistemas, 16 (3). pp:
The payments for environmental services granted by the PSAH were very small, which turned out to be unattractive for the ejidos, especially after having invested an important part in conservation works and not directing anything to benefitting the ejidatarios economically.

It is urgent that the PSAH becomes a profitable plan for the producers and that beyond the five years of backing, it assures continuing to receive income for the conservation of their forests; on the contrary, there is no guarantee that these properties will continue to provide the environmental services that they do now.

The participation of ejido properties in the PSAH does not guarantee that they will be conserved in the long term because the PSAH did not contribute to creating a permanent local mechanism for payments of environmental services. Despite this, the ejidos continue to perform conservation activities in the properties.

\section{- End of the English version -}

137-147.

Návar-Chaídez, José de Jesús. 2011. Los bosques templados del estado de Nuevo León: el manejo sustentable para bienes y servicios ambientales. Madera y Bosques. 16 (1), 2010. pp: 51-69.

Porras, Ina, Maryanne Grieg-Gran, y Nanete Neves. 2008. All that glitters: A review of payments for watershed services in developing countries. Natural Resource Issues No. 11. International Institute for Environment and Development. London. 129 p.

Rodríguez, G. 1996. Metodología de la investigación cualitativa. Ed. Aljiba. Barcelona, España. 378 p.

Ruiz-Pérez, M., C. García-Fernández, y J. A. Sayer, 2007. Los servicios ambientales de los bosques. Ecosistemas. Vol.16. Número 3. pp: 81-90.

Salkind, Neil J. 1999. Métodos de investigación. 3ra edición. Ed. Prentice Hall. México, D.F. 380 p.

SEMARNAT. 2003. Acuerdo que establece las reglas de operación para el otorgamiento de pagos del Programa de Servicios Ambientales Hidrológicos. Secretaría de Medio Ambiente y Recursos Naturales. Diario Oficial de la Federación. 3 de octubre de 2003. México.

SEMARNAT. 2011. Reglas de Operación del Programa ProAr- 
bol 2012. Secretaría de Medio Ambiente y Recursos Naturales. Diario Oficial de la Federación. 21 de diciembre de 2011. México, D. F. 89 p.

Sultana, Zakia, y Paulin Coulibaly. 2011. Distributed modelling of future changes in hydrological processes of Spencer Creek watershed. Hydrological Processes. Vol. 25. Issue 8. April 2011. pp: 1254-1270.
Tague, Christina, y Gordon E. Grant. 2009. Groundwater dynamics mediate low-flow response to global warming in snowdominated alpine regions. Water Resources Research. Vol. 45. W07421. $12 \mathrm{p}$.

Taylor, Richard G. 2013. Ground water and climate change. Nature Climate Change. Vol. 3. April 2013. pp: 322-328. 